\title{
THE ROLE OF TAPHONOMY IN CLADISTIC ANALYSIS: A CASE STUDY IN PERMIAN BIVALVES
}

\author{
Marcello Guimarães SIMÕES ${ }^{\prime}$, Antonio Carlos MARQUES ${ }^{2}$, \\ Luiz Henrique Cruz de MELLO ${ }^{1,3}$, Renato Pirani GHILARDI ${ }^{1,3}$
}

\author{
' Depto de Zoologia, Instituto de Biociências-UNESP/Botucatu, CxP.510, 18618-000 Botucatu SP, \\ BRAZIL.e-mail: btsimoes@ibb.unesp.br \\ 2 Depto de Biologia, FFCLRP-USP, Av. Bandeirantes 3900, 14040-901 Ribeirão Preto SP, BRAZIL. e- \\ mail: marques@ffclrp.usp.br \\ ${ }^{3}$ Depto de Geologia Sedimentar e Ambiental, Inst. Geociências-USP, Programa de Pós-graduação em \\ Geologia Sedimentar, CxP.11348, 05422-970 São Paulo SP, BRAZIL. e-mail: cruzmell@usp.br; \\ ghilardi@usp.br
}

Simões, M.G., Marques, A.C., Mello, L.H.C. de and Ghilardi, R.P. 2000. The role of taphonomy in cladistic analysis: A case study in Permian bivalves. [El papel de la tafonomía en los análisis cladísticos: un caso en los bivalvos pérmicos.] Revista Española de Paleontología, 15(2), 153-164. ISSN 0213-6937.

\begin{abstract}
The Megadesmidae (Bivalvia, Anomalodesmata) fossil record was examined in order to assess the role of taphonomy in cladistic analysis. Megadesmids are thick-shelled, infaunal, suspension-feeding bivalves. Our data indicate that their fossil record seems biased in favor of thick-shelled, shallow-burrowing genera and/or deepburrowing forms. Consequently, there is a relation between the mode of life (shallow versus deep) and the resolution and quality of the fossil record. Deep-burrowers (Vacunella) are often preserved in life position offering a more accurate (temporal and spatial) fossil record, adequate for paleoecological inferences, while shallow-burrower shells (Plesiocyprinella), that are more prone to post-mortem transport and temporal mixing, offer a record with poor spatial and temporal resolution. The identification of homoplasy among infaunal bivalves constitutes a major challenge for their cladistic analysis. Within Megadesmidae intrinsic (bauplan limitations) and extrinsic (better preservational potential) factors favor the occurrence and preservation of homoplasy among the deep-burrowers. The implications are: a) clustering of deep-burrowing bivalves (Vacunella, Roxoa) due to parallel homoplasies, forming "adaptive", not necessarily "evolutive" taxa, and b) lower consistency indices in their cladistic analysis.
\end{abstract}

Keywords: Phylogeny, Cladistics, Paleontology, Taphonomy, Stratigraphy, Paleoecology, Bivalvia, Megadesmidae.

\section{RESUMEN}

Para comprender la relación de la tafonomía y los análisis cladísticos, fue examinado el registro fósil de los Megadesmidae (Bivalvia, Anomalodesmata). Nuestros datos indican que el registro fósil no representa igualmente a todos los taxones. Los bivalvos de concha gruesa, i.e. formas excavadoras superficiales y/o excavadoras de profundidad, están relativamente mejor representados. Parece existir una relación entre el modo de vida de los Megadesmidae y la resolución y calidad del registro fósil. Los excavadores de profundidad (Vacunella) están a menudo conservados en posición de vida o in situ, lo que proporciona un registro temporal y espacial más exacto y, por lo tanto, más adecuado para interpretaciónes paleoecológicas. Los excavadores superficiales (Plesiocyprinella) están más sujetos al transporte post-mortem y al desordenamiento temporal, lo que resulta en datos con baja resolución temporal y espacial. Dentro de los Megadesmidae, factores intrínsecos (limitaciones con relación al "bauplan") y extrínsecos (mejor potencial de preservación) favorecen la aparición y preservación de homoplasia entre los excavadores de profundidad. Las implicaciones son: a) agrupamiento de bivalvos excavadores de profundidad (Vacunella, Roxoa) resultante de homoplasias paralelas, separando los taxones de acuerdo con semejanzas "adaptativas", no necesariamente "evolutivas", y b) bajos índices de consistencia en los análisis cladísticos.

Palabras clave: Filogenia, Cladística, Paleontología, Tafonomía, Estratigrafía, Paleoecología, Bivalvia, Megadesmidae. 


\section{INTRODUCTION}

After 50 years from the first publication of Willi Hennig's classic book (Hennig, 1950), evolutionary studies in paleontology have demonstrated that the evolution of ancient and/or extinct organisms can be successfully reconstructed and consequently phylogenetically interpreted by way of cladistic methodology. However, because of the incompleteness and imperfection of the fossil record (The Origin of Species, Darwin, 1859) many paleontologists still believe that the record must be very incomplete, and thus inappropriate to test evolutionary hypotheses (the inferiority complex, sensu Donovan and Paul, 1998). The main concern here is that we should not ignore the information available in the geological record, but rather find ways to incorporate it in a cladistic approach (Marshall, 1998a, b).

For the reasons above and many others (e.g., Schoch, 1986), cladistics is still viewed as a kind of dogma in some circles of paleontologists throughout the world. However, reliable data have shown for some groups (e.g., bivalve mollusks; Valentine, 1989) that despite the fact that their fossil record may be incomplete, it is adequate for many requirements of paleobiological studies (see Donovan and Paul, 1998, for an up-to-date review of the adequacy and completeness of fossil record). Thus, it could contribute to answer biological questions related to their evolutionary history. In fact, as elegantly commented by Harper (1998:258) "....since the bivalve record appears good, with more than $70 \%$ completeness, it would seem surprising that, despite the widespread use of cladistics in the study of other groups, bivalve workers, both neontologists and palaeontologists, have been extremely slow to embrace its methods." Particularly, in this case, the problem could be related to the widespread recognition of convergence and parallelism in different clades, problems that were considered as limiting factors to the evolutionary scenario (Seilacher, 1984, see also Harper, 1998: 258).

According to Harper (1998), the completeness of the bivalve record calculated for fossil representatives of extant genera with aragonitic shells (that matches the example that will be discussed later) is around $82 \%$. While Skelton et al. (1990) and Skelton and Benton (1993) have suggested that most bivalves lack sufficient characters to use in cladistic analysis (see Heaney, 1995 for an opposite view), a few bivalve workers (e.g., Waller, 1978, 1998; Schneider, 1992, 1995; Roopnarine, 1996; Simões et al., 1997) have published rigorously cladistic studies, examining the phylogeny of different bivalve taxa, using fossil data alone (e.g., Roopnarine, 1996; Simões et al., 1997; Mello et al., 1998a, Mello, 1999) or a combination of data sets including both information from the fossil record and living organisms (e.g., Waller, 1978, 1998; Schneider, 1992, 1995, 1998; Schneider and Magyar, 1999).

As demonstrated by Donovan and Paul (1998), the nature of the fossil record could play an essential role in investigating a particular evolutionary problem (e.g., ancestors). This and other related themes were debated online (Nature debates on-line forum, http://www.helix.nature.com/debates/) recently in response to Smith's question "Is the fossil record adequate?" (Smith, 1998a). A major synthesis of the discussed topics was presented by Smith (1998b). These facts instigated us to investigate the role of taphonomy in the cladistic analysis of the Permian bivalves of the family Megadesmidae.

\section{SOURCE OF DATA}

Megadesmid is a conspicuous group of thick-shelled bivalves known from the Upper Paleozoic marine deposits (e.g., Mendes, 1952; Newell, 1956; Waterhouse, 1965; Runnegar, 1965, 1967, 1974; Runnegar and Newell, 1971). The group represents typical elements from epicontinental seas (Runnegar, 1984) that covered large areas of the Gondwanaland (see Runnegar and Newell, 1974, for rare occurrences outside Gondwana). They were particularly common in Permian deposits of the Paraná Basin [a huge intracratonic depression generated during the Early Paleozoic (Zalán et al., 1991), covering in its Brazilian portion an area of more than 1 million $\mathrm{km}^{2}$ ], specially in a stratigraphical interval encompassing the sediments of Tubarão and Passa Dois groups (Middle-Late Carboniferous to Late Permian) (Simões et al., 1997, 1998b). The gradual confinement of the Paraná Basin toward the end of Permian favored the endemism of the group (Runnegar and Newell, 1971; Simões, 1992; Simões et al., 1998b).

For this study, 37 bivalve rich fossil concentrations from Tubarão (Rio do Sul and Rio Bonito formations, Early Permian, and Palermo Formation, Late Permian) and Passa Dois Group (Serra Alta, Terezina and Corumbataí formations, Late Permian) were analyzed. These are grouped into two distinct "biostratinomic styles": 1 - Thin $(>3 \mathrm{~cm})$, two-dimensional internally simple concentrations (distal tempestites, $\mathrm{n}=11$ ), with disperse, high-organic nacreous aragonitic shells of megadesmid and other anomalodesmatans; 2- Thick (30$50 \mathrm{~cm}$ ), fully tridimensional, internaly complex, amalgamated concentrations $(n=26)$, represented by bioclastic sandstones or coquinas (proximal tempestites), with a mixture of densely-packed, low-organic calcitic shells of veneroid bivalves, and shells of megadesmid bivalves (Simões et al., in press).

Over 3000 specimens were examined and prepared using standard paleontological techniques (Feldmann et al., 1989) and studied for taxonomy, morphology, distribution, mode of fossilization, and overall preservation quality. The material and methods for these were discussed in detail by Simões et al. (1997, 1998b), Simões (1998), Simões and Kowalewski (1998a, b), Ghilardi (1999), Mello (1999) and Torello (1999). In addition, nearly 800 megadesmid specimens from different scientific collections in Brazil (University of São Paulo) were also examined. As a result, a great number of taphonomic (see Torello and Simões, 1994; 
Simões et al., 1996a, b, 1998a, c; Simões and Kowalewski, 1998a, b; Torello, 1999), morphologic (Simões and Anelli, 1995; Simões and Mello, 1996; Ghilardi and Simões, 1997), autoecologic (Ghilardi, 1995; Simões et al., 1998b; Ghilardi, 1999), and phylogenetic (Simões et al., 1997; Mello et al., 1998a; Mello, 1999) data were obtained. Simultaneously, new stratigraphic and biostratigraphic (Santos, 1987; Rohn, 1994; Maranhão, 1995) data for the examined stratigraphical interval became available. All these data were the basis for the discussion made herein. The classification and cladistic phylogeny (Fig. 1) of the megadesmid by Simões et al. (1997) was adopted as the framework for our analysis. The definitions adopted in the ecological classification follows Runnegar (1974).

\section{RESULTS}

The study of the fossil record of the shallow burrowing megadesmid genera (considering only the elements that yield the same bedding plane to avoid the analytical time-averaging, sensu Fürsich and Aberhan, 1990), from concentrations of Rio do Sul (Simões et al., 1998b), Rio Bonito (Rocha-Campos, 1970; Simões, 1998), Palermo (Simões, 1992), Serra Alta, Terezina and Corumbataí formations (Torello and Simões, 1994; Simões, 1998; Simões and Kowalewski, 1998a; Torello, 1999) showed that disarticulation is dominant. Besides, they normally show a broad spectrum of quality of preservation (Torello and Simões, 1994; Simões et al., 1996a; Simões and Kowalewski, 1998a). This is particularly well exemplified by the taphonomic record of Ferraz Shellbed, a $50 \mathrm{~cm}$ thick multievent bed (proximal tempestite), with 4 different Units (Simões and Kowalewski, 1998a, b). In the Unit 2 of Ferraz Shellbed, for example, shallow burrower megadesmids (Plesiocyprinella carinata, Holdhausiella elongata and Favalia arcuata) are exclusively represented by disarticulated shells $(97.3 \%)$. This is also true for the Unit 4 where $95.7 \%$ of shallow and intermediate burrowers are preserved disarticulated (restricting to shallow burrowers only 1 out of 358 shells was articulated). Shells of shallow burrowing genera are not preserved in the Unit 3 (Simões and Kowalewski, 1998a). Other examples are also offered by the fossil record of Myonia tayoensis (Taió Shellbed, Rio Bonito Formation), and Astartila sp. (São Sepé Shellbed, Palermo Formation) that are frequently preserved disarticulated.

On the other hand, deep burrower bivalves, such as Vacunella (Rio do Sul Formation), and some other anomalodesmatans (e.g., Allorisma barringtoni) are often preserved in life position (Simões and Rocha-Campos, 1994; Farro, 1998; Simões et al., 1998a, b). A similar pattern was observed by Veevers et al. (1964) who found 64 specimens of Vacunella preserved in life position, in the same bedding plane of Permian marine deposits of Australia. Deep burrower bivalves, such as Roxoa, are also preserved in Ferraz Shellbed (Corumbataí Formation). Normally, they are preserved with articulated

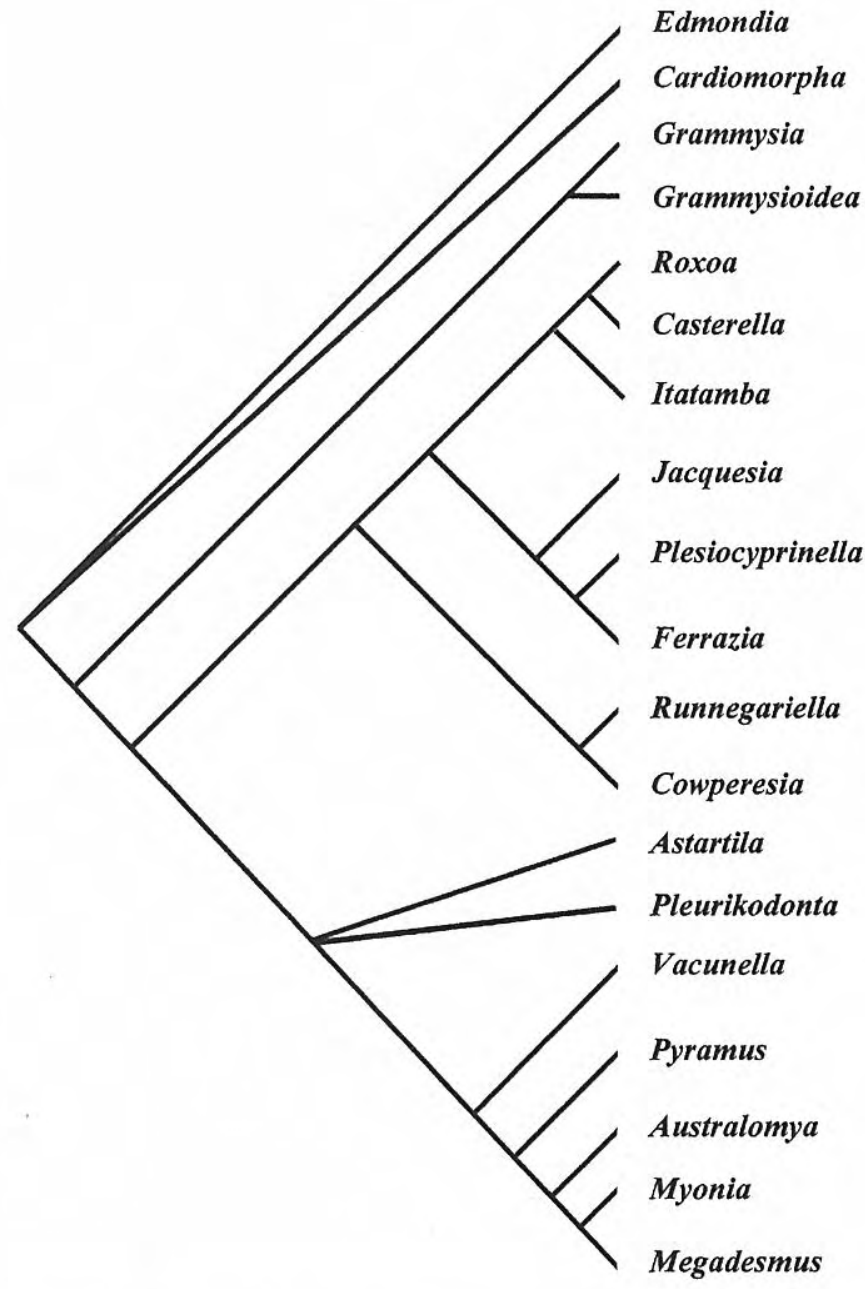

Figure 1. Semi-strict consensus tree $(\mathrm{L}=238 ; \mathrm{CI}=0.87$ : $\mathrm{RI}$ $=0.91$ ) of two cladograms of the family Megadesmidae, according to Simões et al. (1997).

shells, in a stable, reclining position (Simões and Kowalewski, 1998a). In addition, intermediate burrower bivalves, such as Casterella (Terezina and Corumbataí formations), are also commonly preserved articulated, in a reclining position.

The overall quality of preservation (e.g., degree of articulation, abrasion, fragmentation) of the record of the bivalves that are represented by intermediate and deep burrowers seems better than that characterized by shallow burrowers (see Simões et al., 1996a; Simões and Kowalewski, 1998a). For example, while the deep burrowing species Roxoa corumbataiensis (Corumbataí and Terezina Formations) often occurs articulated (closed, butterflied), without signals of abrasion, Ferrazia cardinalis is known only from disarticulated valves, with variable degree of abrasion.

In summary, from the examined record from the Paraná Basin we may conclude that: 1- deep burrower megadesmids are often preserved in life position and/or articulated; 2 - intermediate burrowers are commonly preserved articulated, sometimes in a reclining position, and 3-shallow burrowers are typically preserved as disarticulated elements. 


\begin{tabular}{|c|c|c|c|c|c|c|}
\hline \multicolumn{5}{|c|}{ Platformal Environment } & \multicolumn{2}{|c|}{ Deltaic Environment } \\
\hline $\begin{array}{c}\text { Above } \\
\text { FWB }\end{array}$ & $\begin{array}{l}\text { Above FWB } \\
\text { Lower Limit }\end{array}$ & $\begin{array}{c}\text { Between } \\
\text { FWB/SWB }\end{array}$ & $\begin{array}{c}\text { SWB } \\
\text { Lower Limit }\end{array}$ & $\begin{array}{l}\text { Below } \\
\text { SWB }\end{array}$ & Delta Front & Prodelta \\
\hline $\begin{array}{l}\text { Megadesmus (S) } \\
\text { Myonia (S) } \\
\text { Australomya (I) } \\
\text { Pyramus (I) }\end{array}$ & \begin{tabular}{|l|} 
Megadesmus $(\mathbf{S})$ \\
Astartila (S) \\
Myonia $(\mathbf{S})$ \\
Australomya $(\mathbf{I})$ \\
Pyramus $(\mathbf{I})$
\end{tabular} & \begin{tabular}{|l|} 
Plesiocyprinella(S) \\
Jacquesia $(\mathrm{S})$ \\
Holdhausiella $(\mathrm{S})$ \\
$\oplus$ Ferrazia $(\mathrm{S})$ \\
$\oplus$ Othonella $(\mathrm{S})$ \\
Casterella $(\mathrm{I})$ \\
\end{tabular} & $\begin{array}{l}\text { Myonia (S) } \\
\text { Cowperesia (I) } \\
\text { Vacunella (D) } \\
\text { Roxoa (D) }\end{array}$ & \begin{tabular}{|l|} 
Anhembia $(\mathrm{S})$ \\
Tambaquyra $(\mathrm{S})$
\end{tabular} & \begin{tabular}{|l|}
$\begin{array}{l}\text { Holdhausiella (S) } \\
\text { Casterella (I) }\end{array}$ \\
\end{tabular} & \begin{tabular}{|l|} 
Megadesmus (S) \\
Myonia (I)
\end{tabular} \\
\hline
\end{tabular}

Table 1. Distribution of the megadesmid bivalves in two different environments (platformal, deltaic). Explanations: FWB, fair weather wave base; SWB, storm wave base; S, shallow burrower; I, intermediate burrower; D, deep burrower; shallow burrowing genera with high rates of articulation; shallow burrowing genera known only from disarticulated material. Source of data: Runnegar and Campbell (1976), Simões et al. (1998b) .

\section{DISCUSSION}

\section{TAPHONOMIC IMPLICATIONS}

The data presented above are consistent with the "Reciprocal Taphonomic Model", proposed by Kowalewski (1997). As a first statement, one could expected that, on average, the shells of shallow burrowers are more prone to post-mortem transport and temporal mixing, than the deep burrower shells (see Kondo, 1997, 1998, for a similar pattern). Probably the shells of shallow burrowing megadesmids will offer, for example, poor spatial resolution, while the deep burrowers will have a more accurate temporal and spatial record, better for paleoecological inferences. However, the "negative" consequence is that the evolution of the deep burrower mode of life involves homoplasy between bivalves of different clades (Stanley, 1970; Runnegar, 1974; Seilacher, 1984).

Table 1 shows the distribution of megadesmid genera along a bathymetric gradient in two siliciclastic environments (platformal and deltaic). Note that the shallow burrowing bivalves often occur above the fair weather wave base or between the fair weather wave base and the storm wave base, where waves, currents and flows can exhume and rework the bioclasts. Their occurrence in the more destructive portion of the marine environment and their more exposed strategy of life (sensu Kondo, 1998) could explain the overall predominance of disarticulated shells among the shallow burrowers. On the other hand, in Paraná Basin, deep burrowers, such as Vacunella, occurs in platform siltstones (Rio do Sul Formation) deposited near or below the storm wave base (Simões et al., 1998b). Thus, this deep burrowing genus occurs in the part of the bathymetric gradient where the episodes of abrupt sedimentation must have been more frequent (see Miller et al., 1988; Brett et al., 1997, for similar examples). Not surprisingly, the shallow burrowing genera (e.g., Anhembia; Serra Alta Formation) that have high rates of articulation are those that are preserved in situ in sediments deposited below the storm wave base (Mello et al., 1998b).

Additionally, Simões (1998) and Simões and
Kowalewski (1998a, Fig. 10) observed that in internally complex concentrations from Rio Bonito (e.g., Taió Shellbed), Corumbataí and Terezina formations (e.g., Ferraz Shellbed), closed articulated and butterflied elements, normally represented by intermediate and deep burrowers are dominated by specimens showing preservation patterns qualitatively ranked as "good" and "fair".

On the other hand, among the shallow burrowing megadesmids, only Runnegariella $(12.5 \%)$ has a thin shell (Runnegar, 1967, 1968, 1974; Runnegar and Newell, 1971; Simões and Anelli, 1995). Interestingly, Erwin (1996) also noted a prominent role for preservational bias in favor of Early Triassic gastropods with robust and equant shells, and Harper (1998) observed that the bivalve fossil record is biased toward the thick shelled species. Thus, the thick shelled shallow burrower megadesmids will offer a large-scale, paleontological record. On the other hand, the intermediate and deep burrowers will offer a more accurate (temporally and spatially) outcrop-scale, paleoeocological record.

\section{IMPLICATIONS FOR THE ANOMALODESMATAN FOSSIL RECORD}

As demonstrated by Stanley $(1968,1972,1977)$ and Runnegar (1974) the first real pulse of diversification of siphonate bivalves came with the emergence of advanced anomalodesmatans (e.g., Megadesmidae) in the Carboniferous. In figures 2 and 3 , the Phanerozoic record of the three infaunal Anomalodesmatan guilds (shallow, intermediate, deep) is shown. The data were compiled from Moore (ed., 1969), Runnegar (1974) and Morris et al. (1991), to prevent the possible misleading that could be derived from different taxonomic treatments. In general, both results are similar showing the dominance of shallow burrower anomalodesmatans, during the Early Paleozoic, and the rapid development of intermediate and deep burrower forms, during the Late Paleozoic. Still, the data derived from Runnegar (1974) also show the broad development of intermediate and deep burrowers during the Mesozoic and Cenozoic (see also Aberhan, 1994). Obviously, these patterns are in strong agreement with 


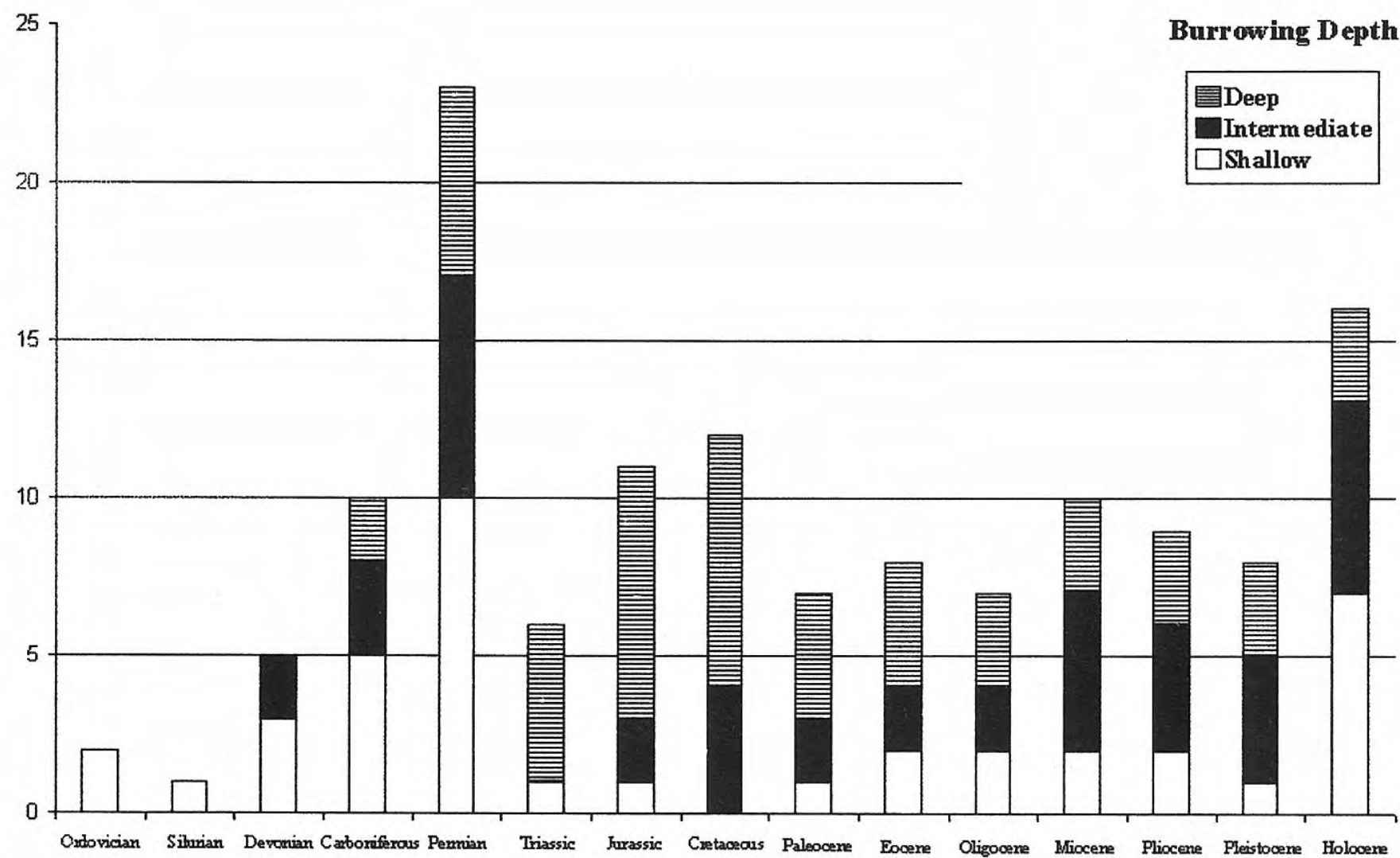

Figure 2. Distribution of the three infaunal anomalodesmatan guilds during the Phanerozic. Source of data: Runnegar (1974).

previous data in literature, according to which the net increase of infaunal organisms was largely controlled by a rise in Mesozoic predation pressure and the adoption of new strategies (Stanley, 1968, 1973, 1975, 1977, 1979, 1990; Nakazawa and Runnegar, 1973; Runnegar, 1974, 1987; Vermeij, 1977, 1987; Skelton et al., 1990; Aberhan, 1994).

Although the factors above explain the broad predominance of infaunal bivalves in the Mesozoic and Cenozoic fossil record, other factors (e.g., preservational potential) may contribute to enhance the pattern within Anomalodesmatans, as indicated by the examination of rates of evolution in the megadesmids. According to several authors, bivalves display a remarkable degree of evolutionary stability (Stanley, 1973, 1977), in part, reflecting eurytopy (Jackson, 1977; Stanley, 1977), low rates of lineage branching and low extinction rates.

Not surprisingly, the intensity of competition has a strong influence on evolutionary turnover, particularly within the non-infaunal invertebrates, since organisms such as infaunal bivalves are not subject to intense competition (Stanley, 1973). Here, the rates of speciation and extinction also vary according with burrowing depth, as well documented by Kauffman (1977) and Stanley (1990).

According to Kauffman (1977), deeper infaunal bivalves have slower evolutionary rates than taxa that have shallow infaunal life habits. On the other hand, fully epibenthic molluks have higher evolutionary rates than those of semi-infaunal or shallow infaunal habits
(Kauffman, 1977; Stanley, 1990). Megadesmidae bivalves seem to show similar pattern, as discussed below.

Considering the scope of Megadesmidae, as defined by Simões et al. (1997), it is possible to quantify the transformation of the burrowing character in the topology. The higher proportion of transformations is from shallow to shallow burrowers $(51.9 \%$ of the total number of transformations); shallow to intermediate burrowers $(11.1 \%)$, intermediate to intermediate (25.9 $\%)$, and intermediate to deep $(7.5 \%)$. Reversals are also present, but only from intermediate to shallow burrowers, representing $3.7 \%$ of transformations. Hence, it is clear that reversals are rather rare, although they are possible. Moreover, if we consider the number of transformations related to the speciation rate, we can conclude that indeed the shallow burrowers have higher speciation, originating $63.0 \%$ of all transformations (intermediates are responsible for the remaining $37.0 \%$ ).

Considering the above results, and re-examining the fossil record of anomalodesmatan bivalves (Figs. 2, 3), some questions arise: Could the dominance of intermediate and deep burrower anomalodesmatans be explained only on an evolutionary basis? If deepburrowers have low speciation rates why is the number of genera of this particular guild higher than that of shallow burrowers in several intervals of the geological record? Indeed, nearly $53.3 \%$ of the examined taxa in the topology of megadesmid cladogram (Simões et al., 1997) (Fig. 1) are shallow burrowers. On the other hand, 


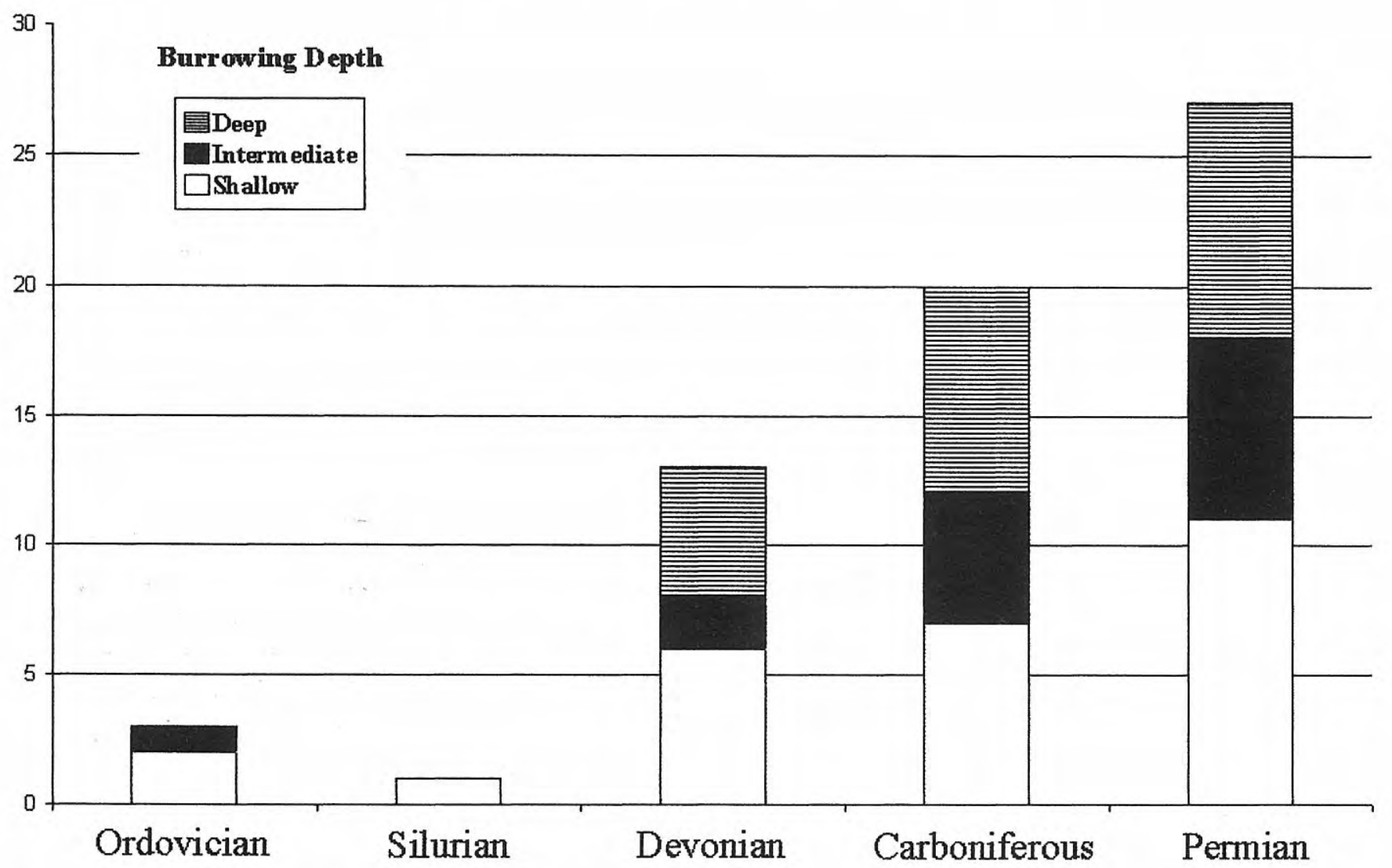

Figure 3. Distribution of mode of life of Paleozoic anomalodesmatan genera. Source of data: Morris et al. (1991).

considering the new cladogram proposed by Mello (1999) (Fig. 4), who added 10 new taxa and 4 new morphological characters to the matrix of Simões et al. (1997), nearly $52.9 \%$ of the genera of the subfamily Plesiocyprinellinae and $42.7 \%$ of the subfamily Megadesminae are shallow burrowers. In addition, Table 2 shows a list of proposed species for Megadesminae. Curiously, in proportion, the number of species of intermediate and deep burrowers is similar to that of shallow burrowers. A similar pattern is also observed for Plesiocyprinellinae bivalves.

Runnegar (1974) and Runnegar and Newell (1974) have envisaged the evolutionary history of the Paleozoic Anomalodesmatan bivalves as a product of a slowly evolving stock of shallow-burrowing species that may have periodically and relatively rapidly produced deepburrowing forms. These authors assumed that this process was frequently irreversible, because deep burrowers are more specialized, and thus, unlikely to produce descendents which lack these adaptations. However, several examples of reversals are known in the fossil record of Bivalvia. Stanley (1972, 1973, 1979), for example, described reversals between epifaunal Arcoida to the ancestral burrowing habit. Reversals were also hypothesized in the family Megadesmidae, in which the shallow-burrowing genera Megadesmus and Myonia evolved by reversal from the intermediate-burrowing forms (Simões et al., 1997). The low proportion of shallow burrowing anomalodesmatans during the
Cretaceous (Fig. 2) is particularly noteworthy. If this is not a false pattern (e.g., misinterpretation of the data available in the literature; lack of record), the "reappearance" of shallow burrowers during the Paleocene is an evidence for either character reversal or a neocolonization of the infaunal habitat by epifaunal organisms. According to Stanley (1990), the reversal cases in arcids and carditids are good examples of the large degree of randomness in bivalve evolution. Thus, if the evolution of the burrowing habit in anomalodesmatan bivalves is not linear (towards a deep-burrowing mode of life; as indicated by evolutionary history of the megadesmids), if deep burrowers have low speciation rates, if reversal process is limited to an intermediate-toshallow burrowers pathway, why is the number of shallow burrowing bivalves not several times greater than that of intermediate and deep burrowers? Could these examples emphasize the potential bias that the evolution of deep burrower strategy may introduce into the fossil record?

\section{METHODOLOGICAL IMPLICATIONS}

We have tried to emphasize the possible relations among taphonomy, paleoecology, and phylogenetic analysis, but the most obvious implication of our results is a methodological one. In Fig. 1, the semi-strict consensus tree of 2 cladograms for the family Megadesmidae (Simões et al., 1997) is shown. Another cladogram, based on Mello (1999), is shown in Fig. 4. 
Figure 4. Strict consensus tree $(\mathrm{L}=286 ; \mathrm{CI}=0.84 ; \mathrm{RI}=$ $0.90)$ of nine cladograms resulted from sucessive weighting analysis, according to Mello (1999).

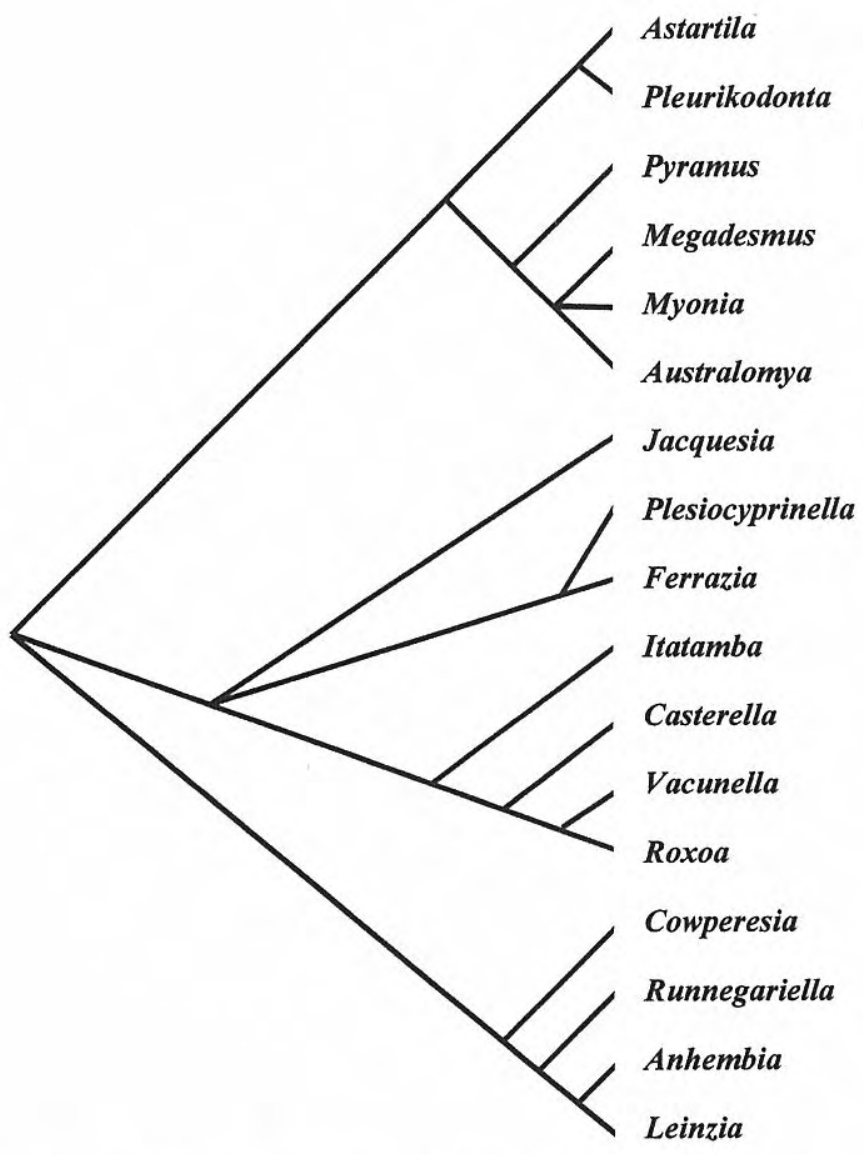

Figure 5. Strict consensus tree of twelve cladograms produced by parsimony analysis, according to Mello et al. (1998a).
Edmondia

Cardiomorpha

Grammysia

Grammysioidea

Astartila

Pleurikodonta

Vacunella

Pyramus

Australomya

Megadesmus

Myonia

Guiratingia

Itatamba

Jacquesia

Relogiicola

Plesiocyprinella

Ferrazia

Casterella

Favalia

Roxoa corumbataiensis

Roxoa intricans

Holdhausiella elongata

Holdhausiella almeidai

Othonella

Tambaquyra

Cowperesia

Runnegariella

Anhembia

Leinzia

Note that the topologies of both cladograms (Figs. 1, 4) are similar to the cladogram presented in Fig. 5 (Mello et al., 1998a). Although the monophyly of the two subfamilies (Megadesminae and Plesiocyprinellinae) was corroborated in the third cladogram (Fig. 5), there is a notable change in the topology that involves the position of the deep-burrower genus Vacunella. The phylogenetic jump of Vacunella from the Megadesminae to the Plesiocyprinellinae, which also includes another deepburrowing taxon (Roxoa), suggests the existence of homoplasy effects due to adaptive characters (burrowing habit). In order to investigate this problem, we carried out an experiment to test the homology of these character states. First we replicated the character codes for burrowing habit in two characters, one for Vacunella (with fake missing data entered for the Roxoa species) and the other for Roxoa (with fake missing data entered for Vacunella). The missing data are a way to challenge 


\section{MODE OF LIFE}

\begin{tabular}{lll} 
Species & Intermediate Burrowers & Deep Burrowers \\
\hline Megadesmus globosus & Australomya hillae & Vacunella curvata \\
Megadesmus nobilissimus & Australomya sulcata & Vacunella etheridgei \\
Megadesmus gryphoides & Australomya dawsonensis & Vacunella sp. 1 \\
Megadesmus recta & Australomya waterhousei & Vacunella sp. 2 \\
Megadesmus ovalis & Australomya sinuosa & Vacunella cf. etheridgei \\
Megadesmus pristinus & Pyramus laevis & Vacunella camachoi \\
Astartila intrepida & Pyramus myiformis & Vacunella ? sp. . \\
Astartila runnegaris & Pyramus ? concentricus & \\
Astartila inflectoventris & Pyramus ? undatus & \\
Pleurikodonta elegans & Pyramus tehuelchis & \\
Pleurikodonta gemma & Pyramus primigenus & \\
Myonia elongata & Pyramus barringtonensis & \\
Myonia valida & Pyramus sp. & \\
Myonia morrisi & & \\
Myonia corrugata & & \\
Myonia carinella & & \\
Myonia tayoensis & & \\
Myonia cyclolirata & & \\
Myonia undata & & \\
Myonia carinata & &
\end{tabular}

Table 2. Number of proposed species for Megadesminae genera. Note the similarity between the number of intermediate and deep burrowing species. Source of data: Mello (1999).

the primary homology (see Pinna, 1991) of the character coding for the taxa. These two replications of the character states were downweighted by the middle of other normal characters to avoid an over-representation of them in the analysis. The result of this new analysis is the same topology of Fig. 4. Surprisingly, Vacunella is not related to Roxoa anymore, and jumped back to the Megadesminae. This suggests that indeed the homology of the character state deep-burrower was a matter of coding, that we have assumed homology among only adaptive characters in previous analysis.

As demonstrated by Runnegar (1966, 1974), Stanley (1970) and Runnegar and Newell (1974), due to basic intrinsic limitations (e.g., "bauplan" limitations), homoplasy is a remarkable feature of burrowing bivalves. This is particularly so for deep-burrowers, that is, those bivalves that in theory have better preservational potential (see Harper and Palmer, 1993, for similar problem in clades of cemented bivalves). As for the Late Paleozoic history of megadesmids, other different group of deep-burrower anomalodesmatans that have evolved during the Mesozoic and Cenozoic are derived from shallow-burrowers (see Runnegar, 1974). In other words, although evolution of the deep burrowing mode of life could have contributed to a better fossil record (e.g., completeness), this has also enhanced preservation of homoplastic characters. Because this phenomenon seems to have occurred several distinct times in different clades during the Phanerozoic (Stanley, 1970; Runnegar, 1974;
Seilacher, 1984; Harper and Palmer, 1993), one could expect that the frequency of homoplasy (at least concerning this character) would increase towards the Cenozoic (Fig. 2). The effects of this increasing of parallel homoplasies could be the artificial clustering of deep burrower bivalves forming polyphyletic taxa. For the cladistic analysis of megadesmids, homoplasy between younger taxa (e.g., Roxoa Late Permian) could obscure the global hierarchy, attracting older taxa (e.g., Vacunella Early-Late Permian). Theoretically, this effect could be avoided only in a broader analysis in which there would have enough characters (in this case nonadaptive) to split the original condition of deep burrowers. Not surprisingly, simulations (Huelsenbeck, 1991; Archie, 1996) have shown that parsimony analysis is less accurate as homoplasy increases and global hierarchy decreases (Wagner, 1998). In this context, another important question must be addressed: since intrinsic factors ("bauplan" limitations, evolution to deepburrow mode of life) and extrinsic (better preservational potential) favor the occurrence and preservation of homoplasy, should we expect lower consistency indices in the cladistic analysis of anomalodesmatan subclass?

\section{FINAL COMMENTS}

Some of the questions above are not entirely new as a general statement (e.g., Schoch, 1986; Smith, 1998b; 
Donovan and Paul, 1998; Harper, 1998), but our data are based on the examination of large collections and field samples that offer sample sizes and collecting resolution (e.g., Simões and Kowalewski, 1998a; Ghilardi, 1999; Mello, 1999; Torello, 1999; Simões et al., 1999) exceeding those of the majority of the previously collected data that are available in the literature. The evidences derived both from taphonomic (Torello and Simões, 1994; Simões et al., 1996a; Simões, 1998; Simões and Kowalewski, 1998a, b) and cladistic studies of the family Megadesmidae (Simões et al., 1997; Mello et al., 1998a; Mello, 1999) suggest that, for this peculiar group of Paleozoic bivalves, taphonomy may influence the results of the phylogenetic analysis. The solution to this problem seems to be difficult. The best approach we can suggest is to concentrate in holistic analysis in which taphonomic and paleoecological interpretations supplement phylogenetic studies.

\section{ACKNOWLEDGMENTS}

We are grateful to the continuous support by FAPESP (Fundação de Amparo à Pesquisa do Estado de São Paulo), including the following research grants: 1993/2747-0, 1994/5021-3, 1996/9708-9, to MGS, and 1996/10544-0; $1997 / 04572-4$ to ACM. Some of the ideas and results presented in this paper originated when MGS was a Visiting Scholar of the Department of Geosciences (The University of Arizona, USA, September, 1998/March, 1999). We thank Karl W. Flessa (The University of Arizona) for many helpful comments on early drafts. The manuscript was greatly improved with valuable reviews by Michal Kowalewski, Sixto Fernández López and Peter W. Skelton. MGS is a CNPq fellow (301023/94-8).

\section{REFERENCES}

Aberhan, M. 1994. Guild-structure and evolution of Mesozoic benthic shelf communities. Palaios, 9, 516-545.

Archie, J.W. 1996. In Homoplasy - the recurrence of similarity in evolution (Eds. M.J. Sanderson and L. Hufford). Academic Press, San Diego. 153-187.

Brett, C., Baird, G.C. and Speyer, S.E. 1997. Fossil Lagerstätten: stratigraphic record of paleontological and taphonomic events. In: Paleontological Events: stratigraphic, ecological, and evolutionary implications (Eds. C.E. Brett and G.C. Baird). Columbia University Press, New York, 3-40.

Darwin, C.R. 1859. The origin of species/ Charles Darwin (Ed. G. Beer). Oxford, The World's classics Series. Oxford University Press, 1996. New York. i- xxxiii, 439 pp.

Donovan, S.K. and Paul, C.R.C. 1998. The adequacy of the fossil record. John Wiley \& Sons, New York. 312 pp.

Erwin, D.H. 1996. Understanding biotic recoveries: extinction, survival, and preservation during the EndPermian mass extinction. In: Evolutionary Paleobiology (Eds. D. Jablonski, D.H. Erwin and J.H. Lipps). The
University of Chicago Press, Chicago, 398-418.

Farro, A.P.C. 1998. Análise tafonômica e paleoecológica das "camadas Allorisma" da Formação Rio do Sul, Subgrupo Itararé: um Lagerstätten do Permiano Inferior, Bacia do Paraná, Brasil. Universidade Estadual Paulista, 59 pp. Unpublished Undergratuate Monography, Institute of Biosciences, Botucatu Campus.

Feldmann, R.M., Chapman, R.E. and Hannibal, J.T. 1989. Paleotechniques. The Paleontological Society, n. 4, Special Publications, $358 \mathrm{pp}$.

Fürsich, F.T. and Aberhan, M. 1990. Significance of timeaveraging for paleocommunity analysis. Lethaia, 23, 143-152.

Ghilardi, R.P. 1995. Paleoautoecologia dos pelecípodes da assembléia Pinzonella illusa Reed, Formação Corumbataí (Permiano Superior), Bacia do Paraná, Brasil. Universidade Estadual Paulista, 59 pp. Unpublished Undergratuate Monography, Institute of Biosciences, Botucatu Campus.

Ghilardi, R.P. 1999. Paleoautoecologia dos bivalves do Grupo Passa Dois (Neopermiano): bivalves fósseis como indicadores da dinâmica sedimentar. Universidade de São Paulo, São Paulo, 160 pp. Unpublished M.Sc. Thesis, Institute of Geosciences.

Ghilardi, R.P. and Simões, M.G. 1997. Muscle scars of a few Permian bivalves (Serra Alta Formation), Paraná Basin. Anais da Academia brasileira de Ciências, 69, 279.

Harper, E.M. 1998. The fossil record of Bivalve molluscs. In: The adequacy of the fossil record (Eds. S.K. Donovan and C.R.C. Paul). John Wiley \& Sons, New York, 243268.

Harper, E.M. and Palmer, T.J. 1993. Middle Jurassic cemented pectinids and the missing right valves of Eopecten. Journal of Molluscan Studies, 59, 63-72.

Heaney, M.J. 1995. Phylogenetic analysis of pristinely preserved Pennsylvanian pelecypods. $15^{\text {th }}$ Canadian Paleontology Conference and International Symposium on the Paleobiology and Evolution of the Bivalvia, Drumheller, Program and Abstracts, 14.

Hennig, W. 1950. Grundzüge einer Theorie der phylogenestichen Systematik. Deutscher Zentralverlag, Berlin. 370 pp.

Huelsenbeck, J.P. 1991. When are fossils better than extant taxa in phylogenetic analysis? Systematic Zoology, 40, 458-469.

Jackson, J.B.C. 1977. Some relationship between habit and biostratigraphic potential of marine benthos. In: Concepts and methods of biostratigraphy (Eds. E.G. Kauffman and J.E. Hazel). Dowden, Hutchinson \& Ross, Inc., Stroudsburg, 65-72.

Kauffman, E.G. 1977. Evolutionary rates and biostratigraphic potential of marine benthos. In: Concepts and methods of biostratigraphy (Eds. E.G. Kauffman and J.E. Hazel). Dowden, Hutchinson \& Ross, Inc., Stroudsburg, 65-72.

Kondo, Y. 1997. Inferred bivalve response to rapid burial in a Pleistocene shallow-marine deposit from New Zealand: Palaeogeography, Palaeoclimatology, Palaeoecology, 128, 87-100. 
Kondo, Y. 1998. Adaptive strategies of soft-bottom, suspension-feeding bivalves to physical disturbance: evidence from fossil preservation. In: Bivalves - An Eon of evolution - paleobiological studies honoring Norman D Newell (Eds. P.A. Johnston and J.W. Haggart). University of Calgary Press, Calgary, 377-392.

Kowalewski, M. 1997. The reciprocal taphonomic model. Lethaia, 30, 86-88.

Maranhão, M.S.A.S. 1995. Fósseis das Formações Corumbataí e Estrada Nova do Estado de São Paulo: subsídios ao conhecimento paleontológico $e$ bioestratigráfico. Universidade de São Paulo, São Paulo, 79 pp. Unpublished Ph.D. Thesis, Institute of Geosciences.

Marshall, C.R. 1998a. Determining stratigraphic ranges. In: The adequacy of the fossil record (Eds. S.K. Donovan and C.R.C. Paul). John Wiley \& Sons, New York, 55-74.

Marshall, C.R. 1998b. Stratigraphic data have a role in phylogenetic analysis. Nature Debates/on-line, November.

Mello, L.H.C. 1999. Análise cladística dos bivalves do Grupo Passa Dois (Neopermiano), Bacia do Paraná: implicações taxonômicas, evolutivas e paleobiogeográficas. Universidade de São Paulo, São Paulo, $160 \mathrm{pp}$. Unpublished M.Sc. Thesis, Institute of Geosciences.

Mello, L.H.C., Marques, A.C., Ghilardi, R.P. and Simões, M.G. 1998a. Taxonomic position of the bizarre permian genera Anhembia and Leinzia and the phylogenetic consistency of the extinct family Megadesmidae (Bivalvia, Anomalodesmata). 17 $7^{\text {th }}$ Meeting of the Willi Hennig Society, São Paulo, Program and Abstracts, 5354.

Mello, L.H.C., Ghilardi, R.P., Torello, F.F and Simões, M.G. 1998b. Some biostratinomic aspects of carbonate concretions from Serra Alta Formation (Late Permian), Paraná Basin, Brazil. $40^{\circ}$ Congresso Brasileiro de Geologia, Belo Horizonte, Anais, 452.

Mendes, J.C. 1952. A Formação Corumbataí na região do Rio Corumbataí (estratigrafia e descrição dos lamelibrânquios). Boletim da Faculdade de Filosofia Ciências e Letras, 145, Geologia, 8, 1-119.

Miller, K.B., Brett, C.E. and Parsons, K.M. 1988. The paleoecologic significance of storm-generated disturbance within a Middle Devonian muddy epeiric sea. Palaios, 3, 35-52.

Moore, R. C. (ed.) 1969. Treatise on Invertebrate Paleontology, Part N, Mollusca 6, Bivalvia. New York, Geological Society of America, University of Kansas Press. 3v. 1224 pp.

Morris, N.J., Dickins, J.M. and Astafieva-Urbaitis, K. 1991. Upper Paleozoic anomalodesmatan bivalvia. Bulletin of the British Museum of Natural History, Geology, 47, 51100.

Nakazawa, K. and Runnegar, B. 1973. The Permian-Triassic boundary: a crisis for bivalves? In: The Permian and Triassic Systems and their mutual boundary (Eds. A. Logan and L.V. Hills). Canadian Society of Petroleum Geologists, Calgary, 608-621.

Newell, N.D. 1956. Primitive desmodont pelecypods of the
Australian Permian. American Museum Novitates, 1979 $1-3$.

Pinna, M.C.C. de 1991. Concepts and tests of homology in the cladistic paradigm. Cladistics, 7, 367-394.

Rocha-Campos, A.C. 1970. Moluscos permianos da Formação Rio Bonito (Subgrupo Guatá), SC. Boletim da Divisão de Geologia e Mineralogia, DNPM, 251, 1-89.

Rohn, R. 1994. Evolução ambiental da Bacia do Paraná durante o Neopermiano no leste de Santa Catarina e do Paraná. São Paulo, Universidade de São Paulo, 2v, 386 pp. Unpublished Ph.D. Thesis, Institute of Geosciences.

Roopnarine, P. 1996. Systematics, biogeography and extinction of Chionine bivalves (Bivalvia: Veneridae) in Tropical America: Early Oligocene-Recent. Malacology, 38, 103-142.

Runnegar, B. 1965. The bivalve Megadesmus Sowerby and Astartila Dana from the Permian of the eastern Australia. Journal of the Geological Society, Australia, 12, 227-252.

Runnegar, B. 1966. Systematic and biology of some desmodont bivalve from the Australian Permian. Journal of the Geological Society, Australia, 13, 373-386.

Runnegar, B. 1967. Desmodont bivalves of the Permian of the eastern Australia. Bulletin of Bureau of Mineral Resources, Geology and Geophysics, Australia, 96, 1-96.

Runnegar, B. 1968. Preserved ligaments in Australian Permian bivalves. Palaeontology, 11, 94-103.

Runnegar, B. 1974. Evolutionary history of the bivalve Subclass Anomalodesmata. Journal of Paleontology, 48, 904-939.

Runnegar, B. 1984. The Permian of Gondwanaland. 27th International Geological Congress, Moscow, Proceedings, 305-339.

Runnegar, B. 1987. Rates and modes of evolution in the Mollusca. In: Rates of evolution (Eds. K.W.S. Campbell and M.F. Day). Allen \& Unwin, London, 39-60.

Runnegar, B. and Campbell, K. S. W. 1976. Late Paleozoic faunas of Australia. Earth Science Reviews, 12, 235-257.

Runnegar, B. and Newell, N.D. 1971. Caspian-like relict molluscan fauna in the South American Permian. Bulletin of the American Museum of Natural History, 146, 1-66.

Runnegar, B. and Newell, N.D. 1974. Edmondia and Edmondiacea shallow-burrowing paleozoic pelecypods. American Museum Novitates, 2533, 1-19.

Santos, P.R. 1987. Facies e evolução paleogeográfica do Subgrupo Itararé/Grupo Aquidauana (Neopaleozóico) na Bacia do Paraná, Brasil. São Paulo, Universidade de São Paulo, 128 pp. Unpublished Ph.D. Thesis, Institute of Geosciences.

Schneider, J.A. 1992. Preliminary cladistic analysis of the bivalve family Cardiidae. Bulletin of American Malacologists, 9, 145-155.

Schneider, J.A. 1995. Phylogeny of the Cardiidae (Mollusca, Bivalvia): Protocardiinae, Laevicardiinae, Lahilliinae, Tulogocardiinae subfam.n. and Pleuriocardiinae subfam.n. Scripta Zoologica, 24, 321-346.

Schneider, J.A. 1998. Phylogeny of stem-group eucardiids (Bivalvia: Cardiidae) and the significance of the transitional fossil Pericardia. Malacologia, 40 (1-2), $37-$ 62. 
Schneider, J.A. and Magyar, I. 1999. Evolution of brackish and freshwater cockles (Bivalvia: Cardiidae) in the Central and Eastern Paratethys. The Geological Society of America Annual Meeting, Denver, 1999, Abstracts with Programs, 31 (7), 173.

Schoch, R.M. 1986. Phylogeny reconstruction in Paleontology. Van Nostrand Reinhold Company, New York. i-x, 353 pp.

Seilacher, A. 1984. Constructional morphology of bivalves: evolutionary pathways in primary versus secondary softbottom dwellers. Paleontology, 27, 207-237.

Simões, M.G. 1992. Pelecípodes da Formação Palermo (Permiano) de São Sepé (RS) e Guiratinga (MT): implicações na evolução da fauna neopaleozóica da Bacia do Paraná, Brasil. São Paulo, Universidade de São Paulo, 286 pp. Ph.D. Thesis, Institute of Geosciences.

Simões, M.G. 1998. Tafonomia, "time-averaging" $e$ resolução espacial de concentrações internamente complexas: um estudo de casos do Permiano da Bacia do Paraná (grupos Tubarão e Passa Dois), Brasil e suas implicações paleoecológicas. Universidade Estadual Paulista, Botucatu, São Paulo, 160 pp. Full-Professor Thesis, Institute of Biosciences.

Simões, M.G. e Anelli, L.E. 1995. Runnegariella, um novo gênero de Megadesmidae (Pelecypoda) da Formação Corumbataí (Neopermiano), Bacia do Paraná, Brasil. Geociências, 14, 161-173.

Simões, M.G. and Kowalewski, M. 1998a. Shell beds as paleoecological puzzles: a case study from the Upper Permian on the Paraná Basin, Brazil. Facies, 38, 175196.

Simões, M.G. and Kowalewski, M. 1998b. Genetic complexity and geobiological implications of "simple" shell beds: an example from the Upper Permian of the Paraná Basin, Brazil. Journal of African Earth Science, 27(1A), 179-180.

Simões, M.G. e Mello, L.H.C. 1996. Sistemática e anatomia funcional de Casterella Mendes, 1952 (Pelecypoda), Formações Terezina e Corumbataí (Permiano superior), Bacia do Paraná, Brasil. Acta Geológica Leopoldensia, 43, 5-23.

Simões, M.G. and Rocha-Campos, A.C. 1994. An autochthonous Late Paleozoic pelecypod assemblage from the Rio do Sul Formation (Permian), Paraná Basin, Brazil. $38^{\circ}$ Congresso Brasileiro de Geologia, Balneário Camboriú, Boletim de Resumos Expandidos..., 206-207.

Simões, M.G., Torello, F.F. e Rocha-Campos, A.C. 1996a. Gênese e classificação da coquina de Camaquã (assembléia de Pinzonella neotropica), Formação Corumbataí (Permiano Superior), Rio Claro, SP. Anais da Academia brasileira de Ciências, 68, 545-557.

Simões, M.G., Torello, F.F., Mello, L.H.C., Passos, J.R.S. e Ghilardi, R.P. 1996b. Aplicação de tafogramas ternários no estudo das assinaturas tafonômicas de concentração fossilíferas da Formação Corumbataí (Permiano), Bacia do Paraná, Brasil. $39^{\circ}$ Congresso Brasileiro de Geologia, Salvador, Anais, 301-302.

Simões, M.G., Marques, A.C., Mello, L.H.C. and Anelli, L.E. 1997. Phylogenetic analysis of the genera of the extinct family Megadesmidae (Pelecypoda, Anomalodesmata), with remarks on its paleoecology and taxonomy. Journal of Compative Biology, 2, 75-90.

Simões, M.G., Kowalewski, M., Torello, F.F. and Anelli, L.E. 1998a. Long-term time-averaging despite abrupt burial: Paleozoic obrution deposits from epeiric settings of Paraná Basin, Brazil. The Geological Society of America Annual Meeting, Toronto, 1998, Abstracts with Programs, 384.

Simões, M.G., Rocha-Campos, A.C. and Anelli, L.E. 1998b. Paleoecology and evolution of Permian pelecypod assemblages (Paraná Basin) from Brazil. In: Bivalves - An Eon of evolution - paleobiological studies honoring Norman D. Newell (Eds. P.A. Johnston and J.W. Haggart). University of Calgary Press, Calgary, 443-452.

Simões, M.G., Torello, F.F., Kowalewski, M., Klein, C., Mello, L.H.C. and Ghilardi, R.P. 1998c. Are the obrution deposits the most precise and best resolved beds in event stratigraphy? Some Paleozoic examples from the Paraná Basin, Brazil. $40^{\circ}$ Congresso Brasileiro de Geologia, Belo Horizonte, Anais, 444.

Simões, M.G., Kowalewski, M., Torello, F.F. and Ghilardi, R.P. 1999. Devonian and Permian benthic marine invertebrates preserved in life position: taphonomic feedback in a Paleozoic epeiric sea. $16^{\circ}$ Congresso Brasileiro de Paleontologia, Crato, 109-110.

Simões, M.G., Kowalewski, M., Torello, F.F., Ghilardi, R. P. and Mello, L.H.C. (in press). Early onset of modernstyle shell beds in the Permian sequences of the Paraná Basin: implications for the Phanerozoic trend in bioelastic accumulations. Revista Brasileira de Geociências, $\mathbf{3 0}$.

Skelton, P.W. and Benton, M.J. 1993. Mollusca: Rostroconchia, Scaphopoda and Bivalvia. In: The Fossil Record (Ed. M.J. Benton). 2, Chapman and Hall, London, 237-263.

Skelton, P.W., Crame, J.A., Morris, N.J. and Harper, E.M. 1990. Adaptive divergence and taxonomic radiation in post-Palaeozoic bivalves. In: Major evolutionary radiations (Eds. P.D. Taylor and G.P. Larwood). Systematics Association Special Volume, 42, Clarendon Press, Oxford, 91-117.

Smith, A. 1998a. Is the fossil record adequate? Nature Debates/on-line, November.

Smith, A. 1998b. Concluding remarks. Nature Debates/online, December.

Stanley, S.M. 1968. Post-Paleozoic adaptive radiation of infaunal bivalve molluscs - a consequence of mantle fusion and siphon formation. Journal of Paleontology, 42, 214-229.

Stanley, S.M. 1970. Relation of shell form to life habits of the Bivalvia (Mollusca). Geological Society of America, Memoir, 125, 1-296.

Stanley, S.M. 1972. Functional morphology and evolution of byssaly attached bivalve mollusks. Journal of Paleontology, 46, 165-212.

Stanley, S.M. 1973. Effects of competition on rates of evolution, with special reference to bivalve mollusks and mammals. Systematic Zoology, 22, 486-506. 
Stanley, S.M. 1975. Theory of evolution above the species level. Proceedings of the Natural Academy of Science, U.S.A., 72, 646-650.

Stanley, S.M. 1977. Trends, rates and patterns of evolution in the Bivalvia. In: Patterns of evolution, as illustrated by the fossil record (Ed. A. Hallam). Developments in Paleontology and Stratigraphy, 5, Elsevier, New York, 209-250.

Stanley, S.M. 1979. Macroevolution, pattern and process. W.H. Freeman and Company, San Francisco, 332 pp.

Stanley, S.M. 1990. Adaptive radiation and macroevolution. In: Major evolutionary radiations (Eds. P.D. Taylor and G.P. Larwood). Oxford Science Publications, Oxford, 116.

Torello, F.F. 1999. Características tafonômicas das concentrações fossilíferas da Formação Corumbataí (Permiano superior), na região de Tambaú, SP, Bacia do Paraná, Brasil. Universidade de São Paulo, São Paulo, 130 pp. Unpublished M.Sc. Thesis, Institute of Geosciences.

Torello, F.F. e Simões, M.G. 1994. Características tafonômicas da assembléia de Pinzonella illusa Reed, Formação Corumbataí (Neopermiano), Bacia do Paraná, Brasil. Acta Geológica Leopoldensia, 39, 159-173.

Valentine, J.W. 1989. How good was the fossil record? Clues from the Californian Pleistocene. Paleobiology, 15, 83-94.

Veevers, J.J., Randal, M.A., Mollan, R.G. and Paten, R.J.
1964. The geology of the Clermont 1:250.000 sheet area, Queensland. Bulletin of Bureau of Mineral Resources, Geology and Geophyics, Australia, 1-66.

Vermeij, G.J. 1977. The Mesozoic marine revolution: evidences from snails, predators and grazers. Paleobiology, 3, 245-258.

Vermeij, G.J. 1987. Evolution and escalation: an ecological history of life. Princeton University Press, Princeton, 527 pp.

Wagner, P.J. 1998. Why phylogenetic hypotheses need testing by stratigraphic data? Nature Debates/on-line, November.

Waller, T.R. 1978. Morphology, morphoclines and a new classification of the Pteriomorphia (Mollusca: Bivalvia). Philosophical Transactions of the Royal Society of London, B284, 345-365.

Waller, T.R. 1998. Origin of the Molluscan Class Bivalvia and a phylogeny of major groups. In: Bivalves - An Eon of evolution - paleobiological studies honoring Norman D. Newell (Eds. P.A. Johnston and J.W. Haggart). University of Calgary Press, Calgary, 1-46.

Waterhouse, J.B. 1965. Generic diagnoses for some burrowing bivalves of the Australian Permian. Malacology, 3, 367-380.

Zálan, P.V., Wolff, S., Vieira, I.S., Astolf, M.A., Conceição, J.C.J., Zanotto, O. and Appi, V.T. 1991. Tectonics and sedimentation of the Paraná Basin. $7^{\text {th }}$ International Gondwana Symposium, São Paulo, Proceedings, 83-117. 